\title{
The Role of Learning Resources, School Environment, and Climate in Transforming Schools from Buildings to Learning Communities
}

\author{
Ines Elezović, Beti Lameva, and Falk Brese
}

\begin{abstract}
International large-scale assessments can play a critical role in identifying factors that have an effect on student learning and achievement. IEA's Trends in International Mathematics and Science Study (TIMSS), as the only international study of primary level mathematics and science education, is increasingly important in supporting continuous improvement in the quality of education and education systems. TIMSS also collects background information about the material and nonmaterial factors that potentially affect teaching and learning processes, and the 2019 cycle of TIMSS provided a unique opportunity to analyze the role these factors play in education across the Dinaric region. Previous research has suggested that there are two especially important sets of socioeconomic background variables that need to be taken into consideration when analyzing possible factors related to student achievement and their attitudes toward teaching and learning at school. These are, firstly, personal student characteristics and their home resources and, secondly, school climate and material resources. Modeling of the TIMSS 2019 data for the Dinaric education systems indicated that material, environmental, and school climate factors were only weakly associated with student achievement across the region, explaining less than $12 \%$ of the variance in student achievement in science and less than $11 \%$ of the variance in mathematics achievement. These results indicate that education authorities in the region should not automatically assume that the material characteristics of the school environment, as well as elements of school climate, are the best or only areas for potential improvement. Access to home learning resources, parental support, and students' and teachers' attitudes toward learning and teaching
\end{abstract}

\footnotetext{
I. Elezović $(\varangle)$

National Centre for External Evaluation of Education, Zagreb, Croatia

e-mail: ines.elezovic@ncvvo.hr

B. Lameva

National Examination Centre, Skopje, Republic of Macedonia

e-mail: betilameva@dic.edu.mk

F. Brese

International Association for the Evaluation of Educational Achievement (IEA), Hamburg, Germany

e-mail: falk.brese@iea-hamburg.de
} 
seem to be more important factors in explaining differences in student achievement across the Dinaric region than previously perceived.

Keywords Bullying $\cdot$ Safety $\cdot$ School climate $\cdot$ School environment $\cdot$ School material resources · Trends in International Mathematics and Science Study (TIMSS)

\section{Introduction}

Around the world, education authorities are interested in identifying factors that have an effect on their students' achievement, instigating educational reforms that enhance positive elements of their systems and diminish any negative effects. International large-scale assessments (ILSAs) are viewed as increasingly important in supporting continuous improvement in the quality of education and education systems. Such worldwide assessments, like those conducted by the International Association for the Evaluation of Educational Achievement (IEA) and the Organisation for Economic Cooperation and Development (OECD), as well as others emerging from European Union (EU) initiatives, report the influence of material and non-material factors on teaching and learning processes. IEA's Trends in International Mathematics and Science Study (TIMSS) is especially important for science, technology, engineering, and mathematics (STEM) because it is the only international study of those subjects at the primary school level.

In general, TIMSS has shown that student achievement around the globe has improved since the study began collecting data and measuring trends in 1995, with many national systems showing increasing achievement at both grades four and eight for the mathematics and science subjects. As Mullis said in 2016: "The positive trends indicate education is improving worldwide, and it's not at the expense of equity between high and low achieving students" (TIMSS PIRLS International Study Center, 2016). With this in mind, we investigated school resources and characteristics of the school environment across the Dinaric region; our aim was to understand what underlying factors promote schools as good, successful, and open places for teaching and learning.

Seven participants from the Dinaric region took part in TIMSS 2019, namely Albania, Bosnia and Herzegovina, Croatia, Kosovo, ${ }^{1}$ Montenegro, North Macedonia, and Serbia. Croatia and Serbia both also participated in TIMSS 2015 (where they tested grade four students). ${ }^{2}$ Both achieved results above the international average in

\footnotetext{
${ }^{1}$ This designation is without prejudice to positions on status, and is in line with UNSCR 1244/1999 (United Nations 1999) and the International Court of Justice (ICJ) Opinion on the Kosovo declaration of independence (ICJ 2010).

${ }^{2}$ Slovenia also participated in TIMSS 2015 (and achieved above the TIMSS international average results in mathematics and science), but did not participate in TIMSS 2019 survey and thus could not take part in this comparative analysis of the Dinaric region.
} 
TIMSS 2015 for grade four science, with Serbia also scoring above the TIMSS international average in grade four mathematics (Croatian student achievement for grade four mathematics was around the TIMSS international average). Both education systems also reported an increase in student achievement in mathematics and science between TIMSS 2011 and TIMSS 2015, mirroring the global trend of improvement in student achievement in the subjects assessed by TIMSS. However, while this improvement continued for mathematics in the 2019 cycle of TIMSS in Croatia, a decline in science achievement was noted (despite still scoring above the TIMSS international average). Meanwhile, in Serbia, both assessment areas showed a decline in student achievement between TIMSS 2015 and TIMSS 2019, and the student mathematics achievement score declined below their TIMSS 2011 score (although still remaining above the TIMSS international average). All other Dinaric systems represented in this report recorded grade four student achievement scores below the TIMSS 2019 international average; among this group, Albania's results were closest to the TIMSS 2019 international average and Kosovo's results furthest from the TIMSS 2019 international average for both the mathematics and science assessment areas.

We were interested in whether available school resources, the school environment, and school climate could be linked to student achievement in the Dinaric region. Prior research (Kutsyuruba et al., 2015) has indicated that these factors may play an important part in developing successful schools and students, but, given that cultural factors may also be involved, the data collected by TIMSS 2019 provides the first opportunity to establish the interacting associations between these factors and student achievement across the Dinaric region.

For the Dinaric participants that were involved in TIMSS 2015 and earlier cycles, there has already been an initial exploration of these concepts and their potential effect. School principals reported that almost three-quarters of all students participating in TIMSS 2015 were "affected" or "affected a lot" by the shortage of resources for mathematics and science instruction. In the Dinaric region at that time, $18 \%$ of Croatian schools reported "more than $25 \%$ students coming from economically disadvantaged homes (and not more than $25 \%$ from economically affluent homes);" in Slovenia this figure was $23 \%$, and it was $44 \%$ in Serbia. For all three participants, better achievement results were noted for students in schools where "more than $25 \%$ of the student body comes from economical affluent homes (and not more than $25 \%$ from economically disadvantaged homes)" than for students in schools in that fell into the other two groups, which contained proportionally more students from disadvantaged homes (Martin et al., 2016; Mullis et al., 2016a). Almost a fifth of primary schools in Croatia, a quarter of primary schools in Slovenia, and half of the primary schools in Serbia contained students from homes with (relatively) harsh socioeconomic conditions, and it is perhaps not unexpected that this would have a negative effect on learning and teaching in these schools. Many ILSAs, such as OECD's Programme for International Student Assessment PISA and IEA's TIMSS and Progress in International Reading Literacy Study (PIRLS), have highlighted the importance of home environment in supporting student success (Martin et al., 2016; Mullis et al., 2016a, 2017, 2020; OECD, 2019c). 
Similarly, teachers surveyed in TIMSS 2015 reported having "moderate to severe problems" with school conditions and resources for $17 \%$ of students in Slovenia, $23 \%$ of students in Croatia and $35 \%$ of students in Serbia. It is interesting to note that, in all three participants, students from schools that teachers had identified as strongly affected by such problems nevertheless tended to record higher average achievement in mathematics and science than less affected students. The TIMSS 2015 international results indicated that, generally, students with teachers who reported that their school had no problems with resources had the highest achievement, and students with teachers who reported that their school was "affected a lot" by problems with conditions and resources had the lowest average achievement among their peers (Martin et al., 2016; Mullis et al., 2016a), which seems more in line with expectations. To explain the apparent deviation in the relationship between material resources at school and achievement in the Dinaric region, some research has suggested that, in conditions when material resources are lacking, teachers (and other staff) tend to give more attention to students' learning and are more available and willing to help as a form of compensation (OECD (2019a).

Another general conclusion from TIMSS 2015 was that according to parents, principals, and teachers, as well as students themselves, the majority of grade four students were attending good schools. On average, across all TIMSS 2015 participants, $58 \%$ of parents were reportedly very satisfied with students' school performance, $52 \%$ of teachers were very satisfied with their jobs, more than half the teachers and principals reported that their school achieved a high level of academic success or that there was very strong emphasis on academic success in their school $(>60 \%)$, and the majority of students $(66 \%)$ reported a strong sense of school belonging. In the Dinaric region, the patterns found followed these general conclusions (Martin et al., 2016; Mullis et al., 2016a).

In TIMSS 2015, school climate was represented by a composite TIMSS "Safe and Orderly School" scale (Martin et al., 2016; Mullis et al., 2016a). In general, TIMSS 2015 found that the majority of grade four students were in safe school environments (56\%, according to teachers) and, according to principals, $59 \%$ of schools had "hardly any discipline problems." Conversely, $16 \%$ of all students reported that they were bullied about once a week in their schools, which perhaps challenges teachers' and principals' generally positive perceptions of school safety and school climate. The percentage of students that reported being bullied in TIMSS 2015 was close to the TIMSS international average in Slovenia (14\%), but below the TIMSS international average in Croatia and Serbia (8\%). In TIMSS 2015, 76\% of students in Croatia attended schools where hardly any discipline problems were reported by their principals. Principals in Serbia and Slovenia were more critical than principals in Croatia about the state in their schools (they reported that while around $50 \%$ of students were in schools with "hardly any problems", more than one third of them were in schools with "minor problems"). When teachers were asked to assess safety and order in their schools, they were more cautious than principals in their assessment, with around half reporting that students were in "very safe and orderly schools" in Croatia (48\%) and Serbia (52\%), while Slovenian teachers were more critical in their assessment (around 29\%). In Serbia and Slovenia, students belonging to the 
schools that teachers reported as being very safe and orderly also tended to achieve the highest scores in mathematics in science. In Croatia, there was no significant difference in the achievement between the groups.

Almost half of the students in Serbia (49\%), and more than a half of the students in Croatia $(61 \%)$ and Slovenia $(82 \%)$ had teachers reporting that teaching mathematics and science was somewhat or very limited by student needs (Martin et al., 2016; Mullis et al., 2016a). In Croatia and Slovenia, students whose teachers reported that teaching was not at all limited achieved the best scores in mathematics. This was also true for the science achievement results for Slovenia, but it was interesting that students whose teachers reported that teaching was somewhat or very limited by students needs only scored a few points less on the TIMSS achievement scale. Serbia's results were quite different, and students whose teachers reported that teaching was very limited by students needs tended to achieve the best scores in both mathematics and science. The TIMSS 2019 data showed similar patterns for Croatia and Serbia (Mullis et al., 2020).

While it is important to assess conditions in schools, as a source of material and environmental support to promote student learning, a student's home resources for learning (both in terms of material assets and cultural capital) are well-proven indicators of student success in school (Matković et al., 2019; Meinck et al., 2018). In TIMSS 2015, students whose parents reported many home resources for learning had much higher achievement than students whose parents reported some or few resources. The difference in achievement between the students with many home resources (17-18\%) and those with few resources (8-9\%) was 142 points for mathematics and 141 for science. A similarly massive difference was reported by PIRLS 2016, and, in both TIMSS 2015 and PIRLS 2016, students whose parents reported often spending time with their children on early literacy and numeracy learning activities had a higher achievement than students whose parents did so only sometimes or almost never (Mullis et al., 2017).

The conceptual model of effective schools within the PIRLS and TIMSS studies was also put to test. An effective school was perceived as safe and orderly, had adequate facilities and equipment and well-resourced classrooms, was staffed with well-prepared teachers, it supported academic success, and provided effective instruction. Martin and Mullis (2013, p. 8) concluded, "After controlling for home background, of the school environment variables, Schools Are Safe and Orderly was related to higher achievement in at least one subject in 15 countries, and Schools Support Academic Success in 10 countries. Students Engaged in Reading, Mathematics, and Science Lessons was the most powerful school instruction variable, related to higher achievement in at least one subject in 15 countries, again after controlling for home background. All in all, a school that was safe and orderly, promoted academic excellence, and provided engaging instruction, could be considered to have several important characteristics for effectiveness."

Resources for education are generally focused on physical conditions for schooling, such as having enough space for classes, and ensuring basic utilities and perhaps specialized classrooms are available. More recent discussion on material resources in schools often refers exclusively to the availability of information and 
communication technologies (ICT) in schools, namely whether students have access to equipment such as laptops, tablets, broadband internet, interactive classrooms, and e-libraries. Both of these aspects are addressed in the TIMSS background questionnaires (TIMSS \& PIRLS International Study Center 2018). Digital skills have been noted as being increasingly important in almost all aspects of teaching and learning, in acknowledgment of the need to prepare today's students to function as tomorrow's digital workers (Fraillon et al., 2020). ${ }^{3}$ The integration of ICT is brings some new innovative forms of teaching in classrooms all over the world, having both advantages and disadvantages (Eickelmann, 2011).

OECD's PISA also researches the relation between student achievement and material investments in education, and has repeatedly concluded that investing in the school system initially has positive effects on achievement, but a point is eventually reached when additional investments have a more modest effect on student results and other factors become more important. Essentially, when everything material has been resolved, less tangible elements of the quality of processes of teaching and learning will still need to be tackled to achieve more advanced results. Nevertheless, there are always exceptions, as OECD (2019a, p. 56) noted, "While an inadequately resourced education system cannot deliver good results, Estonia, with a level of expenditure on education that is about $30 \%$ lower than the OECD average, is nevertheless one of the top-performing OECD countries in reading, mathematics and science."

When international large-scale assessments deliver their results, additional research on available data is performed in almost every country around the world. In Croatia, PISA 2006 data showed that home socioeconomic indicators, along with the region of residence, explained $24 \%$ of the variance in students' science achievement and confirmed how important these factors are for student achievement (Gregurović $\&$ Kuti, 2010). As PISA only tests students aged 15, more information is needed at other school levels to make informed decisions about schooling. Reflecting on the results from international data prompts at least two questions about the relationship between material resources available to students and their success measured in terms of knowledge attainment in important learning areas. First, can provision of resources in school overcome the lack of resources at the individual (student, home) level? Secondly, can school characteristics, such as open school climate or a positive school culture oriented towards achievement and academic belonging, overcome a lack of material resources both on the individual and school level?

In general, previous studies have established more indicative connections between student achievement and school environments and school climate (Bear et al., 2014; OECD, 2019b; Schulz et al., 2010), than between student achievement and school material resources. For instance, TIMSS 2015 results have shown that, for almost all grade four students, a positive sense of school belonging was related to higher average mathematics and science achievement (Martin et al., 2016; Mullis et al., 2016a).

\footnotetext{
${ }^{3}$ Here the term "digital" does not simply refer to digital machines and processes, but to the entire political, social, and economic context and infrastructure within which they have emerged. We now live in a "digital age" (Burston et al., 2010, p. 215).
} 
Having in mind that one of the most important goals of every teaching process is to help students become future prosperous adults by putting emphasis on both cognitive outcomes and affective dimensions (attitudes, values, and beliefs), educational systems that aim to be successful should go beyond procurement of material resources. Investing in the continuous professional development of teachers and principals is commonly recommended as a means of ensuring quality education, but other recommendations include investment in developing transversal (lifelong learning) skills or widening use of ICT in school (Drigas \& Vasiliki, 2015; OECD, 2019d; UNESCO [United Nations Educational, Scientific and Cultural Organization], 2014; Webb \& Cox, 2004).

\section{Methodology and Research Questions}

We aimed to investigate whether a particular set of contextual factors was related to achievement, and if and to what extent these factors represented important elements of school life. Our research was designed to address the relative importance of two factors that previous research has suggested may be associated with student achievement. Firstly, how important were school material resources and the school physical environment (in terms of general wealth or plurality of school possessions, i.e., important school equipment and spaces or lack of thereof), school location, and principals' perceptions of the affluence of the families from which enrolled students come from. Secondly, how important was the overall school climate? The elements of school climate here include the social determinants of everyday school life, such as student issues that affect teaching, safe and orderly school environments (as reported by teachers), and bullying among students (as reported by students).

From this we distil three critical research questions:

(1) How well equipped with material resources for learning are schools across the Dinaric region?

(2) What can TIMSS tell us about the learning environment in schools across the Dinaric region?

(3) How comparable are important aspects of school climate across the Dinaric region?

We used data collected by TIMSS 2019 from seven educational systems across the Dinaric region in our analyses. These included students' achievement results at grade four in mathematics and science, and contextual information derived from responses to the students', teachers' and principals' questionnaires. For more information about samples, methods, procedures, and data that we used, see Sect. 5 and the TIMSS 2019 technical report (Martin et al., 2020). 


\subsection{Indicators and Variables Used}

We identified several variables and scales in the TIMSS 2019 international reports as being of potential interest for our research (Table 1). We investigated one of the main aspects of schooling by creating two indexes to assess the availability of material resources in schools, one for mathematics and one for science. These indexes combined teachers' and principals' responses to questions about whether the school possessed a number of specific items (such as computers or a library) and the prevalence of different conditions posing obstacles for teaching into a simple summative "Index of School Material Resources" (see Table 1 and Tables S.8 and S.9 in the supplementary materials available for download at www.iea.nl/publicati ons/RfEVol13).

The Index of School Material Resources combines information collected by TIMSS 2019 on the availability of computers during mathematics/science lessons, existence and size of the school library, existence of classroom libraries, provision of digital learning resources, and instruction being affected by mathematics/science lessons resource shortages. The Index of School Material Resources for teaching science comprised one additional variable about the availability of a dedicated science laboratory in the school. For both mathematics and science, we split the derived index into three categories: (1) few resources available, (2) some resources available, and (3) many resources available in the school (see Table S.10 in the supplementary materials available for download at www.iea.nl/publications/RfEVol13).

Among the contextual data TIMSS collects, there are several indicators regarding the school environment. In the school questionnaire, principals were asked whether the school is situated in an urban or rural settlement and about student composition in their school (if more students come from disadvantaged homes or more students come from affluent home backgrounds). We analyzed the relationship between student achievement and the factors creating the school environment (whether the school was located in an urban or rural environment and the school principal's assessment of the school composition). These demographic determinants have been of interest to researchers for decades, in their attempts to define what conditions underlie student achievement; higher student achievement has been linked to urban and/or wealthier environments (see chapter "Scaffolding the Learning in Rural and Urban Schools: Similarities and Differences" for more information on this topic).

The third factor that we addressed was school climate, which we reduced to the aspect of perceptions of safety and order within school. Defining school climate is complex, despite often being cited as an important explanatory factor for many student outcomes (Brand et al., 2008; Cohen et al., 2009; Hoy et al., 1991). TIMSS reports have consistently shown a positive relationship between student achievement and teachers' and principals' reports that the school is safe and orderly (Martin et al., 2016; Mullis et al., 2016a, 2020). The TIMSS scale on student bullying in school, reported by students themselves, is also important element of assessing the overall safety and state of interrelations within the school and thus included into this analysis (Martin et al., 2020). In TIMSS frameworks bullying is defined as 


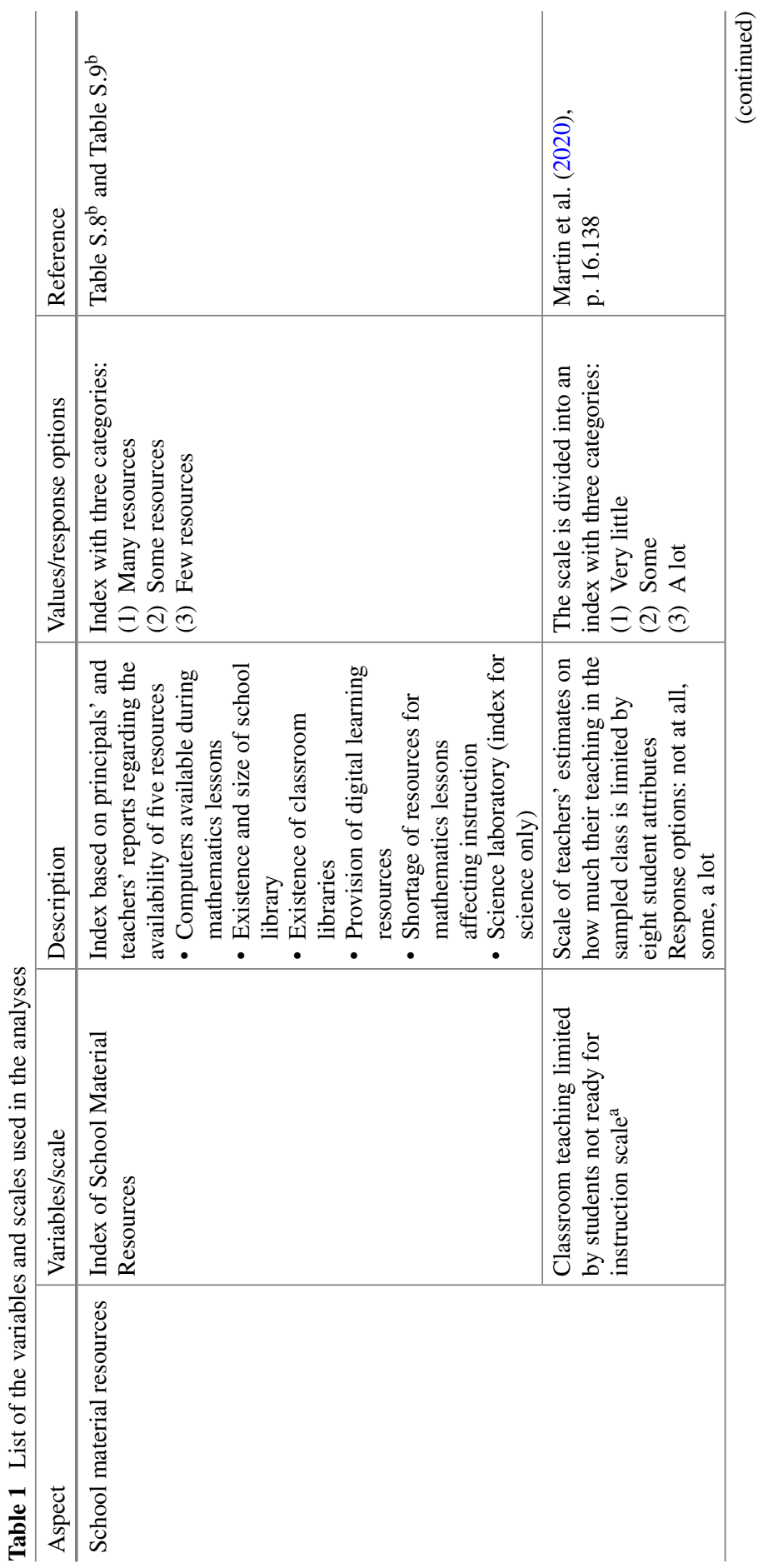




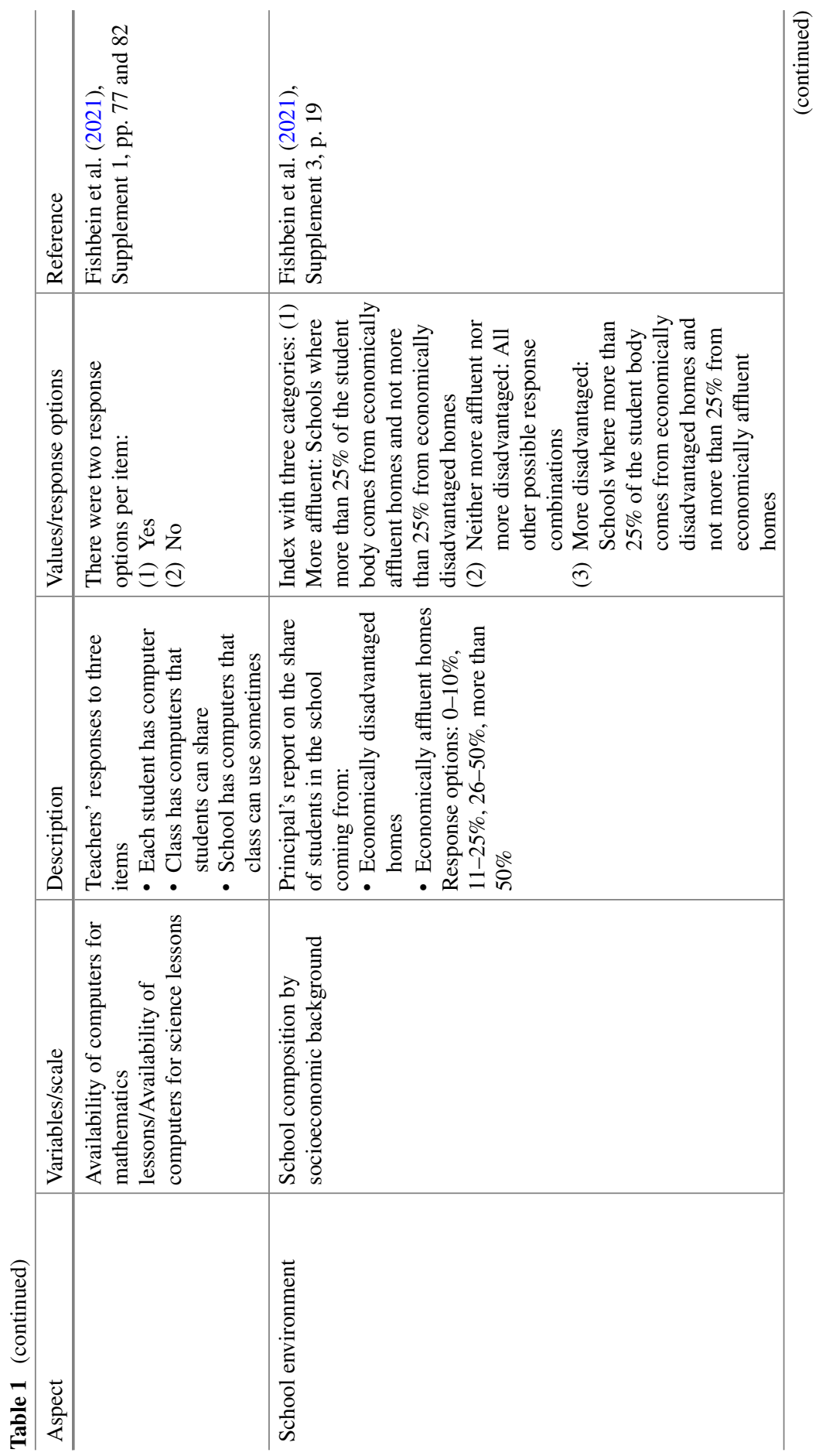




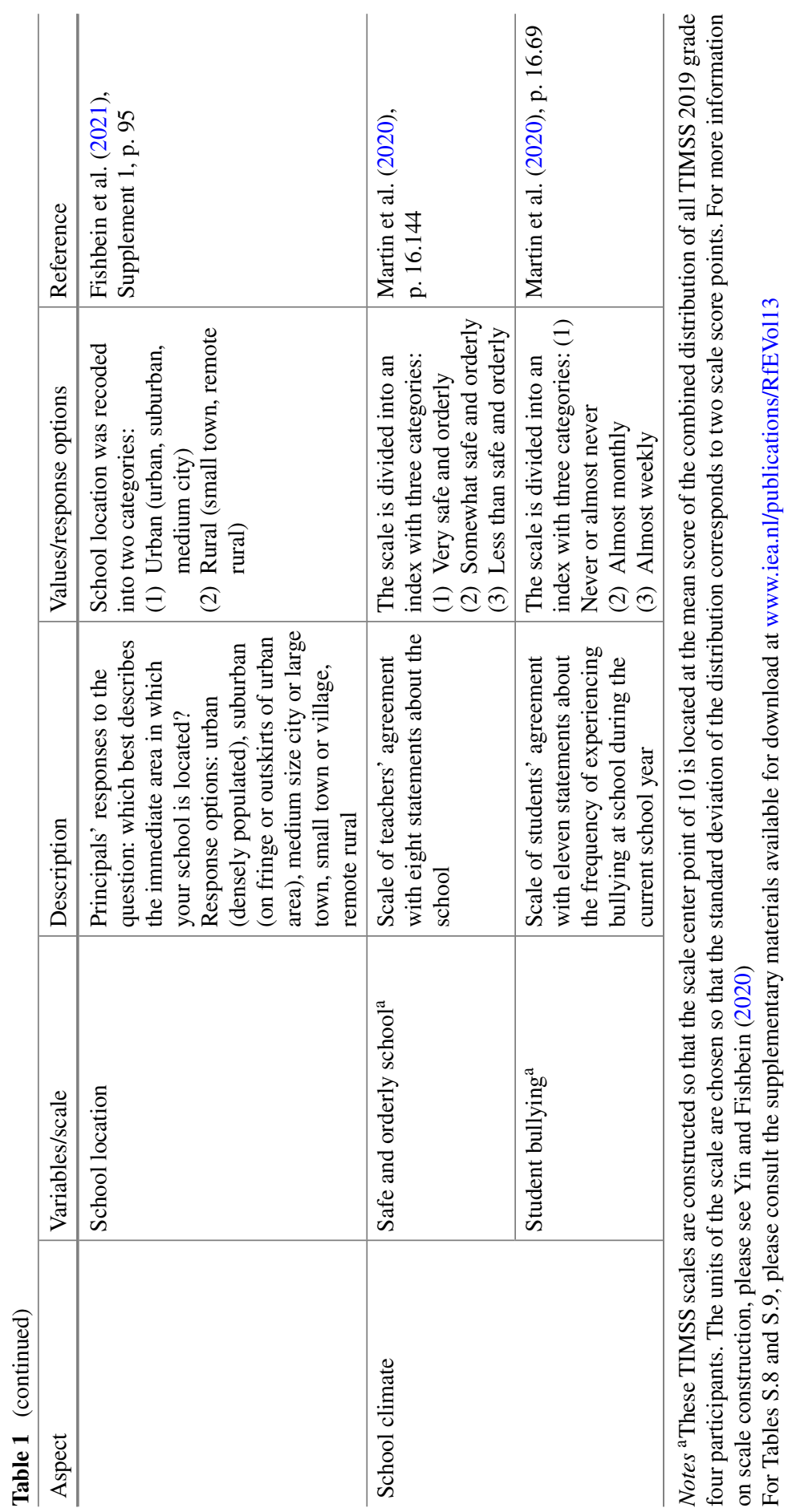


"repeated aggressive behavior that is intended to harm students who are physically or psychologically less strong, and takes a variety of forms ranging from name calling to inflicting mental and physical harm" (Mullis and Martin 2017, p. 68). For some, this may be perceived as narrowed perspective of the concept of school climate, which is why we chose to analyze both the physical and social dimensions of school life in an attempt to provide a multidimensional approach. We thus undertook a comparative analysis of teachers' perspectives on safety and order at school and students' reports on bullying (aggregated at school level). As many national authorities around the world are aware, and the TIMSS 2019 international report reconfirmed (Mullis et al., 2020), the question of school safety (i.e., student bullying) remains an important problem in education. The teacher Safe and Orderly School scale encompasses of eight statements: one asking about conditions outside of the school (i.e., safety in the neighborhood), three about teachers' subjective feeling of safety and order within the school, and another three about students' adherence to school discipline (respecting the rules, teachers and property). We categorized students as being in "very safe and orderly schools" if, on average, their teachers agreed a lot with four of the eight statements and agreed a little with the other four statements.

Another indicator that we used to assess school climate was the TIMSS 2019 scale named "Classroom Teaching Limited by Students Not Ready for Instruction," which is composed of eight variables collected by the TIMSS teacher questionnaire. These questions assess teachers' perceptions of the severity of different limitations that negatively affect their classes. Teachers were asked whether their students lacked prerequisite knowledge or skills, suffered from lack of basic nutrition or not enough sleep, were absent from class, disruptive or disinterested, had to deal impairments (either mental, emotional or psychological), or did not understand the language of instruction.

We used these variables as predictors in regression analyses that investigated whether those elements of school life were related to student achievement.

\section{Results}

\subsection{Material Resources for Learning in Schools}

\subsubsection{Index of School Material Resources}

As explained in Sect. 2.1, we created two indexes to explore the effects of school material resources, one for mathematics and one for science; the science material resources index contained one additional variable (availability of a science laboratory in the school). Not having a science laboratory in school was related to lower achievement results in science only in one system (Albania). In Montenegro, there was no difference in science achievement among the students in schools with or without a science laboratory, and in Bosnia and Herzegovina, Croatia, and Kosovo, 
the difference was small and insignificant. In Montenegro and Serbia, students from schools without science laboratories achieved higher scores in science (more than 10 points higher on average) than those in schools with a science laboratory.

We further examined principals' reports about conditions for teaching related to shortage of resources. Across the Dinaric region, relatively few students were affected either "somewhat" or "a lot" by shortages of resources for mathematics and science instruction, with the lowest percentages reported in Kosovo, Albania, and North Macedonia $(<8 \%)$, and the highest percentage of affected students in Serbia (20\%).

These results seem to differ from teachers' reports; this may be because principals are either less aware of the resource problems reported by their teachers or less willing to admit classroom resource issues. The distribution of material resources for mathematics lessons varies significantly across the region (Fig. 1). Data from Bosnia and Herzegovina, Croatia, Montenegro, North Macedonia, and Serbia were quite consistent, with more than half to two-thirds of students belonging to the intermediate category that enjoys "some resources" (from 57\% in North Macedonia to $76 \%$ in Croatia). In Albania and Kosovo, however, almost two-thirds of all students attended schools where principals indicated that their school was equipped with comparatively few resources. Only six percent of students in Albania were reported as having "many resources" and, in Kosovo, no students fell into this category. In interpreting these statistics, it is important to note that our school material resources scale and/or constructed index was comprised of physical objects and spaces, while, in the TIMSS 2019 schools questionnaire, principals responded to questions on shortages directly aimed at identifying specific issues, such as providing contents and tools that assisted

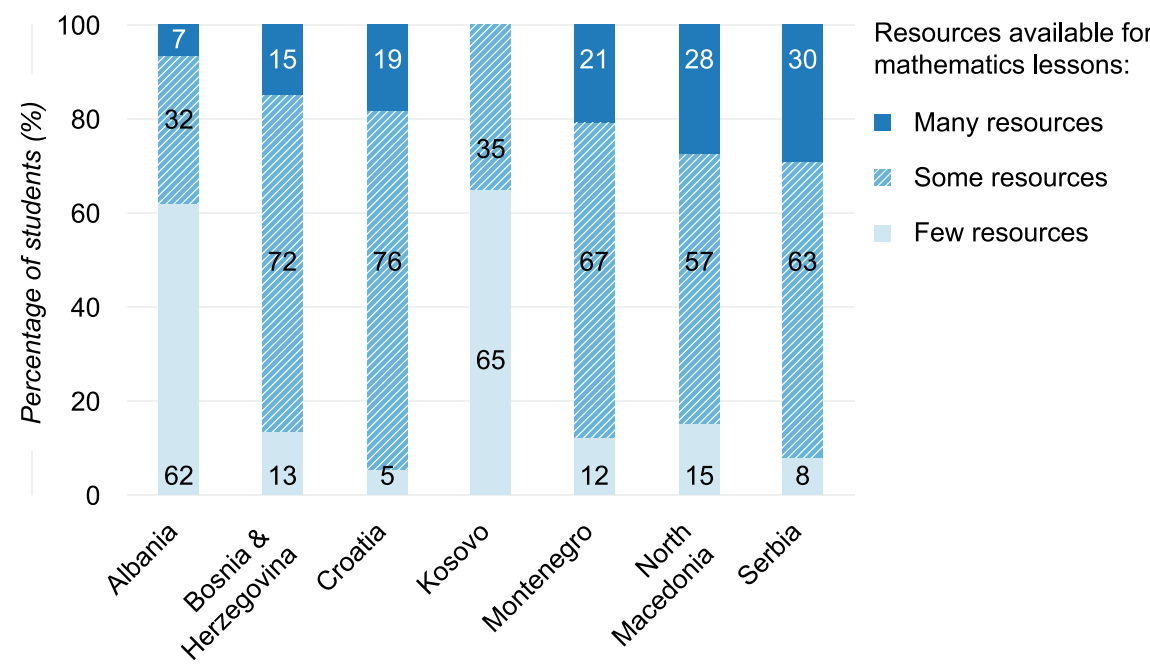

Fig. 1 Index of School Material Resources for Mathematics. Percentage of students in schools with different amounts of resources for mathematics lessons. Note In Kosovo and Serbia, the national defined population covers $90-95 \%$ of the national target population 


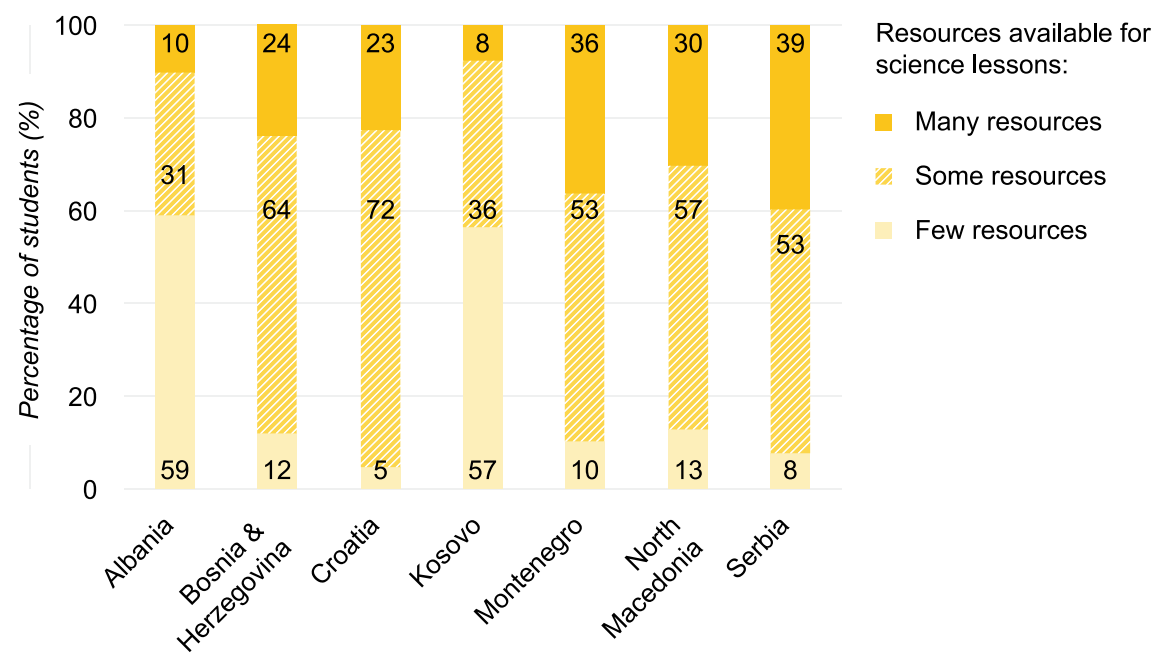

Fig. 2 Index of School Material Resources for Science. Percentage of students at schools with different amounts of resources for science lessons. Note In Kosovo and Serbia, the national defined population covers $90-95 \%$ of the national target population

teaching, along with questions about the availability of specialized staff (teachers); this last question was of particular interest to STEM education in the Dinaric systems.

The distribution of material resources for science lessons was very similar (Fig. 2). In Montenegro, North Macedonia, and Serbia, principals' reports indicated that around half the students belonged to the intermediate category of "some resources". Around two-thirds of students were in this category in Bosnia and Herzegovina (64\%) and Croatia (72\%), and around a third in Albania (31\%) and Kosovo (36\%). Croatia and Serbia had the smallest number of students in the category with "few resources" (5\% and 8\%, respectively), while Albania and Kosovo had the smallest number of students in the category of "many resources" (10\% and 7\%, respectively).

Using the Index of School Material Resources, we found that, in three of the Dinaric participants, differences in mathematics achievement among students at schools were related to the amount of resources. In Albania, on average, students at schools with some resources scored 40 points more than students at schools with only few resources, and students at schools with many resources scored, on average, 73 points more than their peers at schools with few resources. In Croatia, students at schools with few resources, on average, scored 25 points less on the mathematics scale than students at schools with some or many resources. In Serbia, there was a 35 point achievement gap between students at schools with low resources and those at schools with many resources. However, we found no significant similar achievement gaps in Bosnia and Herzegovina, Kosovo, Montenegro, and North Macedonia. Regarding science achievement, we found similarly that students at schools with more resources on average tended to score higher on the TIMSS assessment, except in Montenegro; however, the achievement gap was only significant in Albania (Fig. 3). 
(a)

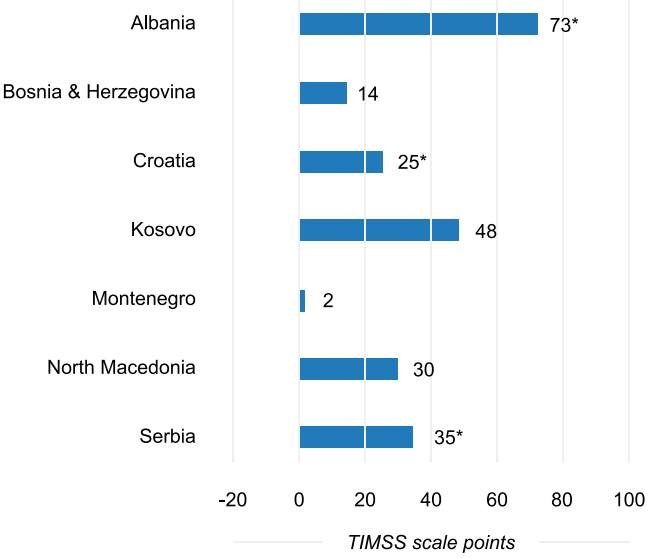

(b)

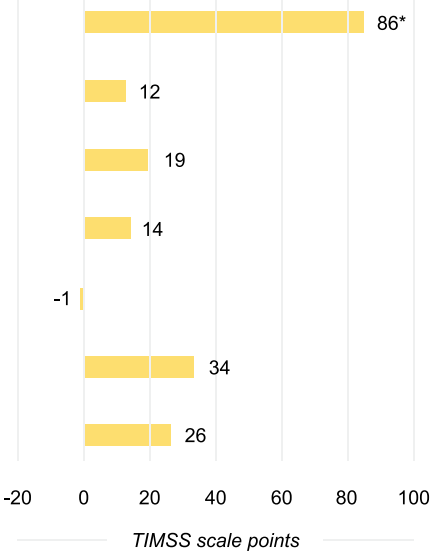

Fig. 3 Difference in $\mathbf{a}$ mean mathematics achievement and $\mathbf{b}$ mean science achievement between TIMSS achievement scores for students at schools with many resources and students at schools with few resources. Notes $*$ The difference is statistically significant $(p<0.05)$. In Kosovo and Serbia, the national defined population covers $90-95 \%$ of the national target population

\subsubsection{Information and Communication Technology Resources}

We found that, on average across the Dinaric region, most students were in schools that were equipped with computers for class use, with the highest percentages in Croatia (97\% both for mathematics and science lessons) and the lowest in Kosovo (54\% for mathematics lessons) and Macedonia (63\% for science lessons) (Fig. 4). When teachers were asked whether each student had a computer to use in mathematics and/or science classes, the situation differed; the highest percentages were in Bosnia and Herzegovina (36\% for mathematics and 30\% for science), and lowest in Kosovo and Serbia $(\leq 3 \%)$. The computer-student ratio ranged widely across the region, from 0.14 in Albania and Kosovo, 0.22 in Serbia, 0.24 in Croatia, 0.25 in Montenegro, and 0.41 in Bosnia and Herzegovina, to 0.77 in North Macedonia.

As well as providing hardware, there is a more sophisticated aspect to ICT in schools, reflected by the construction of online networks through interactive tools and the publication of online content for teaching and learning, such as providing digital learning resources. The progress toward full integration of ICT into teaching and learning has been largely gradual up until 2020, when the COVID-19 pandemic threw education systems around the world into "overnight" digitalization, whether they were prepared for it or not. Across the Dinaric region, TIMSS 2019 data indicated that the provision of "online learning management systems" differed substantially (Table 2). Principals reported that students' access to digital learning resources was good (Table 2). 
(a)

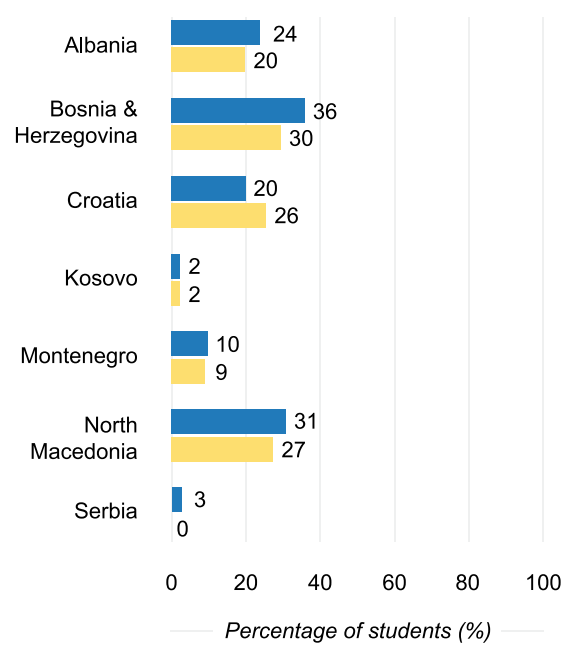

(c)

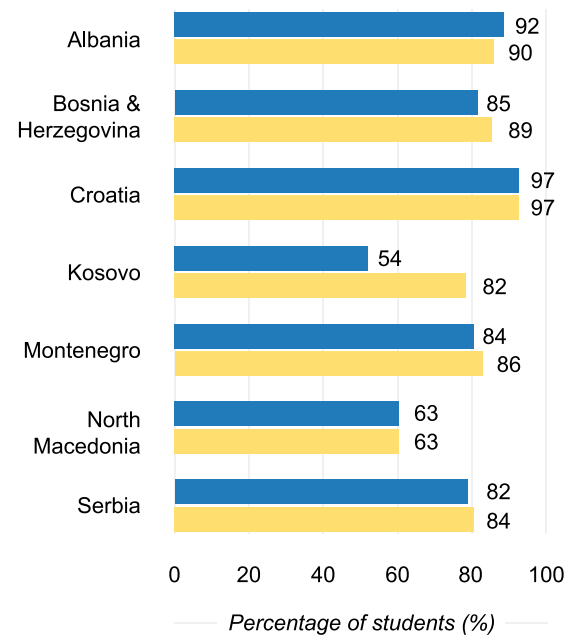

(b)

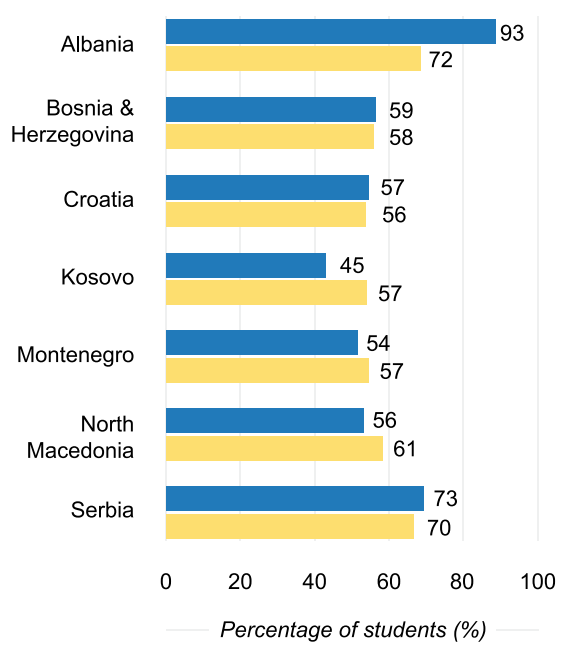

$$
\begin{aligned}
& \text { Access to } \\
& \text { computers in: } \\
& \text { Mathematics } \\
& \text { lessons } \\
& \text { Science } \\
& \text { lessons }
\end{aligned}
$$

Fig. 4 Student access to computers in school for mathematics and science lessons: a percentage of students in classes where each student has a computer; $\mathbf{b}$ percentage of students in classes that have computers for students to share; and c percentage of students in schools that have computers for class use. Note In Kosovo and Serbia the national defined population covers 90-95\% of the national target population.

\subsection{School Environments Across Dinaric Countries}

In terms of school location, more than half of the students are located in urban areas in all seven participants, with the highest percentage in Montenegro (85\%) and the lowest percentages in Croatia and Kosovo (57\%). In general, more students 
Table 2 Principals' reports of access to digital resources in TIMSS 2019

\begin{tabular}{|c|c|c|c|c|}
\hline \multirow{2}{*}{$\begin{array}{l}\text { Education system } \\
\text { Albania }\end{array}$} & \multicolumn{2}{|c|}{$\begin{array}{l}\text { Schools have access to online } \\
\text { learning management systems (\%) }\end{array}$} & \multicolumn{2}{|c|}{$\begin{array}{l}\text { Students have access to digital } \\
\text { learning resources }(\%)\end{array}$} \\
\hline & 15 & (2.9) & 26 & (3.8) \\
\hline Bosnia \& Herzegovina & 27 & (3.3) & 47 & $(4.2)$ \\
\hline Croatia & 50 & (4.3) & 80 & (3.6) \\
\hline Kosovo $^{\mathrm{a}}$ & 13 & $(3.0)$ & 31 & $(4.3)$ \\
\hline Montenegro & 46 & $(0.5)$ & 63 & $(0.5)$ \\
\hline North Macedonia & 62 & (4.6) & 68 & (3.8) \\
\hline Serbia $^{\mathrm{a}}$ & 71 & (3.5) & 76 & (3.4) \\
\hline
\end{tabular}

Notes Standard errors appear in parentheses.

a National defined population covers $90-95 \%$ of the national target population

attend urban schools, and more disadvantaged students tend to attend schools situated in rural areas (see chapter "Scaffolding the Learning in Rural and Urban Schools: Similarities and Differences" for a more detailed analysis of this topic).

According to their principals, the percentage of students at more disadvantaged schools ranged from $13 \%$ in Croatia to $42 \%$ in Albania. Principals in North Macedonia reported that $66 \%$ of students were in more affluent schools; this was the highest perceived percentage for that category in the Dinaric region.

Previous research (Mullis et al., 2016a; OECD, 2019a) has shown that student achievement in mathematics is related to student home socioeconomic status or school principals' perceptions of family affluence. Our analysis of the TIMSS 2019 results confirmed these findings. The students from more affluent schools tended to achieve the best TIMSS mathematics scores in every system in the Dinaric region except Kosovo. In five participants, the mathematics achievement of students at more affluent schools was higher than that of students from more disadvantaged schools, with the biggest achievement gaps in North Macedonia (44 points) and Albania (39 points). In Bosnia and Herzegovina and Kosovo, there was no statistically significant difference between these groups.

As with mathematics, students from more affluent schools tended to achieve the best TIMSS science scores in every system in the Dinaric region except Kosovo. In six participants, the science achievement of students at more affluent schools was higher than that of students from more disadvantaged schools, with the biggest achievement gaps in North Macedonia (50 points) and Albania (42 points). In Kosovo, there was no statistically significant differences between these groups.

We also assessed results related to the TIMSS scale "Teaching Somewhat or Very Limited by Students not Ready for Instruction" (Mullis et al., 2020, exhibits 10.10 and 10.11). Teachers generally reported that relatively few limitations were created by students who were not yet ready for instruction, at least in comparison with other TIMSS participants. In Albania, 71\% of students attended schools that were affected "very little" by students not ready for instruction; in Kosovo $63 \%$ of students attended schools that were affected "very little" and, in North Macedonia, this was $60 \%$. In 
the other participants, less than half of the students had teachers who reported facing few issues (49\% in Croatia and Serbia, 46\% in Montenegro, and 45\% in Bosnia and Herzegovina). At least a third of students in the region had teachers that reported experiencing "some" or "a lot" of limitations due to students not ready for instruction.

\subsection{School Climate: Safety and Order at Schools}

When we assessed perceptions of safety and order in schools, we found that teachers' perceptions of this dimension of school climate differed quite considerably across the region (Table 3 ).

Teachers of almost all students in Albania perceived their schools as very safe and orderly places, but only about half of the students in Croatia had teachers who thought their schools were very safe and orderly. In general, across the Dinaric region, only small percentages of students attended schools perceived by their teachers as "less then safe and orderly" ( $\leq 3 \%)$, and, in most participating systems, except Croatia, there were also fairly low percentages of students in schools that teachers perceived as "somewhat safe and orderly" (Table 3).

According to students, student bullying was present and relatively widespread in the Dinaric region. The percentages of students who reported frequent (monthly or weekly) bullying ranged from $15 \%$ of students in Albania to $32 \%$ of students in North Macedonia. Numerous national and international reports have reported findings on school violence in the Dinaric region. For example, when looking at adolescent experiences, the United Nations Children's Fund (2017) reported that a quarter of

Table 3 Percentage of students by how safe and orderly their school environment was, according to their teachers

\begin{tabular}{|c|c|c|c|c|c|c|}
\hline \multirow{3}{*}{$\begin{array}{l}\text { Education } \\
\text { system }\end{array}$} & \multicolumn{6}{|c|}{ Teacher reported school was: } \\
\hline & \multicolumn{2}{|c|}{$\begin{array}{l}\text { Very safe and orderly } \\
\text { (\% students) }\end{array}$} & \multicolumn{2}{|c|}{$\begin{array}{l}\text { Somewhat safe and } \\
\text { orderly (\% students) }\end{array}$} & \multicolumn{2}{|c|}{$\begin{array}{l}\text { Less than safe and } \\
\text { orderly (\% students) }\end{array}$} \\
\hline & 97 & (1.3) & 3 & (1.3) & 0 & $(0.0)$ \\
\hline $\begin{array}{l}\text { Bosnia \& } \\
\text { Herzegovina }\end{array}$ & 80 & $(2.8)$ & 14 & (1.7) & 0 & $(0.0)$ \\
\hline Croatia & 47 & $(3.2)$ & 52 & $(3.2)$ & 1 & $(0.7)$ \\
\hline Kosovo $^{\mathrm{a}}$ & 91 & $(2.3)$ & 9 & $(2.4)$ & 0 & $(0.0)$ \\
\hline Montenegro & 85 & (1.7) & 14 & (1.7) & 0 & $(0.0)$ \\
\hline $\begin{array}{l}\text { North } \\
\text { Macedonia }\end{array}$ & 76 & (3.4) & 22 & (3.4) & 1 & $(0.7)$ \\
\hline Serbia $^{\mathrm{a}}$ & 73 & $(4.2)$ & 24 & (4.0) & 3 & (1.4) \\
\hline
\end{tabular}

Notes Standard errors appear in parentheses

a National defined population covers $90-95 \%$ of the national target population

Source Mullis et al. (2020), exhibits 8.7 and 8.8 
students in Albania and North Macedonia experienced bullying in schools. Dinaric educational systems have strongly promoted zero violence policies in schools in response to this problem, and prevention programs have also been developed to tackle internet and cyber-bullying.

We analyzed the TIMSS 2019 data on bullying at school level in relation to school material resources, for both mathematics and science, and identified no significant differences between the schools belonging to the groups with few and many resources for learning (Figs. 5 and 6).

In general, we note that the education systems that scored higher on the Indexes of School Material Resources were not experiencing lower levels of bullying in schools.

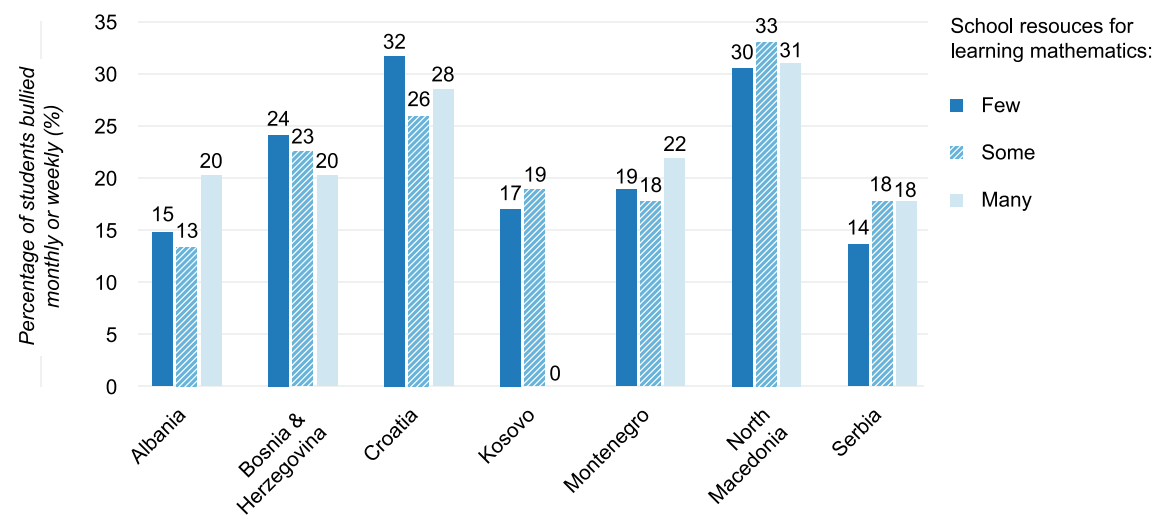

Fig. 5 Percentages of students being bullied monthly or weekly in schools versus school resources for learning mathematics. Note In Kosovo and Serbia, the national defined population covers 90-95\% of the national target population

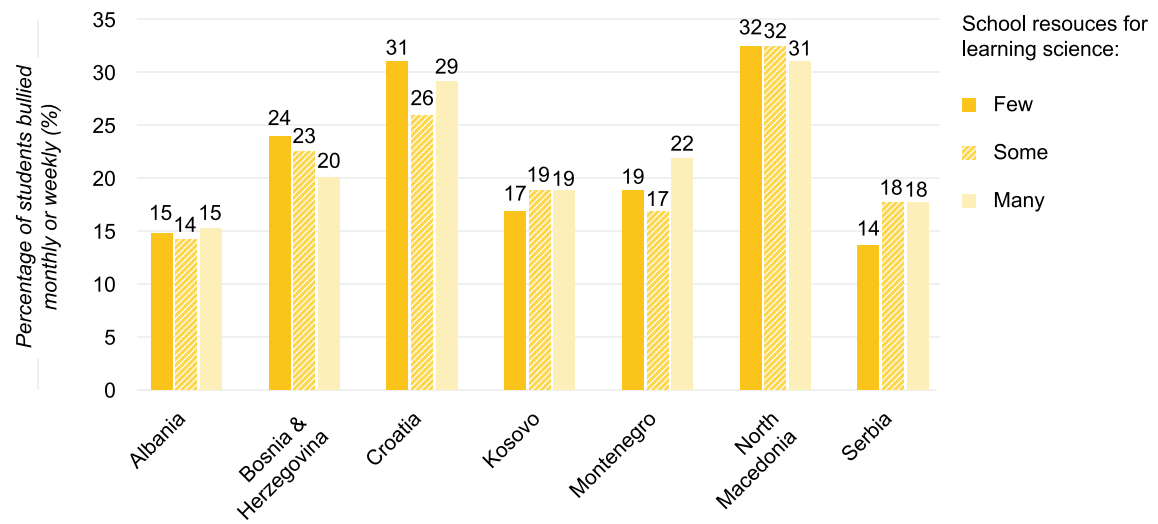

Fig. 6 Percentages of students being bullied monthly or weekly in schools versus school resources for learning science. Note In Kosovo and Serbia, the national defined population covers 90-95\% of the national target population 
A focus on developing more intangible elements, such as a supportive school climate, a culture of achievement, and trust in school as an institution, may result in better environments for teaching and learning within schools.

\subsection{Impact of the Schools' Material Resources, Environment, Composition and Climate on the Achievement Results (Regression Analysis)}

Having investigated the effects of several school-related factors on achievement, we undertook multivariate regression modeling to obtain a more comprehensive picture how all these factors were interrelated with achievement. The regression analyses revealed that the importance and significance of the factors varied across the region. We found that the Index of School Material Resources, and the school environment and climate factors explained only two percent of variance in student achievement in mathematics in Bosnia and Herzegovina, Croatia, and Montenegro, six percent of variance in Serbia, seven percent in Kosovo, and up to $11 \%$ of variance in Albania and North Macedonia (Table 4). The regression models also only explained two percent of variance in student achievement in science in Bosnia and Herzegovina, Croatia, and Montenegro, seven percent of variance in Kosovo and Serbia, and up to $12 \%$ of variance in Albania and North Macedonia (Table 5). The low power of variables related to school resources, school environment, and school climate in explaining student achievement strongly suggests that factors related to students' home resources and the personal characteristics of students (interests, motivation, beliefs), and teachers' and teaching characteristics together play a much greater part in supporting student achievement, as other chapters in this book confirm.

\section{Conclusions}

Around the world, education authorities are interested in supporting better learning for all and international large-scale assessments play a critical role in identifying and supporting solutions that affect student achievements (Mihaljević Kosor et al. 2019). Although ILSA results sometimes lead researchers and policymakers to suggest that student achievement can be improved simply by something as obvious as investing in material resources, our research reveals that the answers are much more complex. Looking at the Dinaric region alone, factors related to material resources, school environment, and school climate did not show uniform or particularly strong effects on student achievement, although there were some interesting patterns that were aligned with the wider international results. In the TIMSS 2019 international results, higher average achievement in mathematics and science at grade four was associated with fewer school resource shortages and higher school emphasis on academic success 


\begin{tabular}{|c|c|c|c|c|c|c|c|c|c|}
\hline \multirow{2}{*}{\multicolumn{2}{|c|}{ 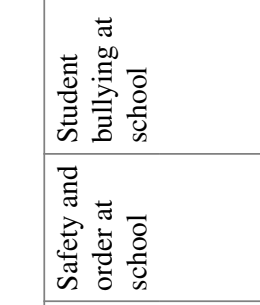 }} & 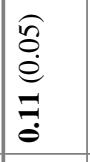 & $\begin{array}{l}\widehat{\partial} \\
\stackrel{0}{0} \\
\stackrel{0}{0} \\
0 \\
0\end{array}$ & $\begin{array}{l}\sqrt{8} \\
0 \\
0 \\
0 \\
0 \\
0 \\
0\end{array}$ & $\begin{array}{l}\tilde{8} \\
\stackrel{8}{0} \\
\stackrel{0}{9} \\
0\end{array}$ & $\begin{array}{l}\widehat{a} \\
\stackrel{\delta}{0} \\
0 \\
\stackrel{0}{0}\end{array}$ & $\begin{array}{l}\frac{\pi}{8} \\
0 \\
0 \\
\frac{1}{0} \\
-0\end{array}$ & $\begin{array}{l}\frac{1}{8} \\
0 \\
0 \\
0 \\
0\end{array}$ & \\
\hline & & 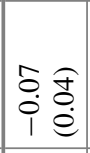 & O̊d & $\begin{array}{l}0 \\
0 \\
0 \\
i \\
i\end{array}$ & $\begin{array}{l}5 \\
\vdots \\
i \\
i \\
\end{array}$ & $\begin{array}{ll}0 & \widehat{\delta} \\
0 & 0 \\
i & 0\end{array}$ & to & $\begin{array}{l}\infty \\
0 \\
0 \\
0 \\
i\end{array}$ & \\
\hline \multicolumn{2}{|c|}{ 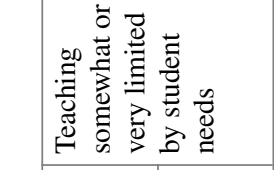 } & $\begin{array}{l}\frac{1}{8} \\
\dot{0} \\
0 \\
0 \\
0\end{array}$ & 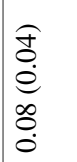 & $\begin{array}{l}\hat{f} \\
0 \\
e \\
0 \\
0 \\
0\end{array}$ & $\begin{array}{l}0 \\
8 \\
0 \\
0 \\
0 \\
0\end{array}$ & $\begin{array}{l}\widehat{c} \\
\stackrel{8}{0} \\
0 \\
0 \\
0\end{array}$ & $\begin{array}{l}0 \\
\delta \\
e \\
\\
0 \\
0 \\
0\end{array}$ & $\begin{array}{l}\hat{f} \\
0 \\
e \\
0 \\
0 \\
0 \\
0\end{array}$ & 苞 \\
\hline \multirow{2}{*}{ 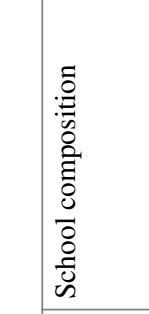 } & 总 & 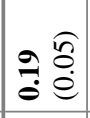 & \&: & $\stackrel{a}{8}$ & 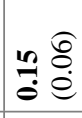 & 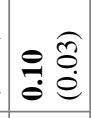 & $\stackrel{\hat{0}}{\stackrel{0}{0}}$ & 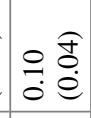 & \\
\hline & 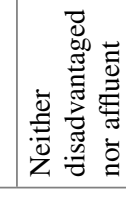 & 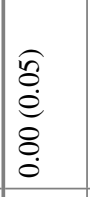 & \begin{tabular}{|l} 
fo \\
0 \\
0 \\
0 \\
0 \\
0
\end{tabular} & 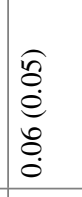 & $\begin{array}{l}0 \\
8 \\
e \\
0 \\
0 \\
0 \\
0\end{array}$ & $\begin{array}{l}\hat{0} \\
\stackrel{0}{0} \\
0 \\
0 \\
0 \\
0\end{array}$ & $\begin{array}{l}\tilde{r} \\
0 \\
e \\
0 \\
0 \\
0 \\
0\end{array}$ & $\begin{array}{l}\frac{\sigma}{8} \\
\dot{e} \\
0 \\
0 \\
0 \\
0\end{array}$ & \\
\hline \multicolumn{2}{|c|}{ 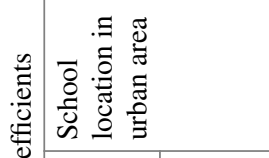 } & $\begin{array}{l}0 \\
0 \\
0 \\
e \\
0 \\
0 \\
0\end{array}$ & $\begin{array}{l}\hat{\sigma} \\
\stackrel{0}{0} \\
0 \\
0 \\
0\end{array}$ & 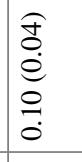 & 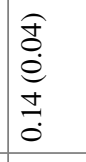 & $\begin{array}{l}\hat{a} \\
\stackrel{0}{0} \\
0 \\
0 \\
0\end{array}$ & $\begin{array}{l}\hat{n} \\
\stackrel{0}{0} \\
n \\
0 \\
0\end{array}$ & $\begin{array}{l}\widehat{\tilde{o}} \\
\dot{0} \\
\infty \\
0 \\
0 \\
0\end{array}$ & \\
\hline 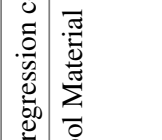 & 窟 & 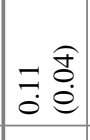 & 蒫 & $g \stackrel{a}{\dot{\theta}}$ & & ח̊: & $\overbrace{0}^{0} \frac{\varrho}{0}$ & 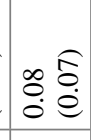 & \\
\hline 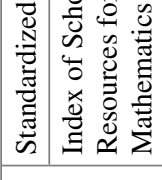 & 焉 & 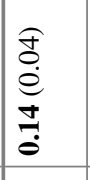 & $\begin{array}{l}\frac{1}{0} \\
\stackrel{0}{0} \\
0 \\
0 \\
0\end{array}$ & $\begin{array}{l}\hat{E} \\
0 \\
0 \\
0 \\
0\end{array}$ & $\begin{array}{l}\hat{f} \\
0 \\
0 \\
0 \\
0 \\
0 \\
0\end{array}$ & $\begin{array}{l}\widehat{0} \\
\stackrel{0}{0} \\
0 \\
0 \\
i \\
i\end{array}$ & 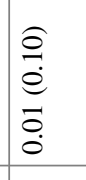 & \begin{tabular}{|l}
$\hat{E}$ \\
0 \\
0 \\
$o$ \\
0 \\
0
\end{tabular} & \\
\hline 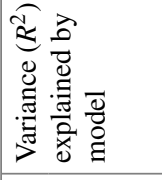 & & $\stackrel{9}{0}$ & ô. & Oे. & 官 & $\begin{array}{l}\tilde{O} \\
0 \\
0\end{array}$ & $\bar{F}$ & 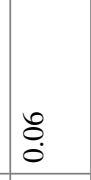 & \\
\hline 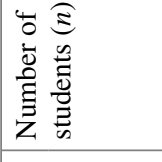 & & 点 & 总 & $\mid$ & $\frac{O}{i}$ & बे & 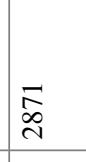 & $\overrightarrow{\bar{y}}$ & \\
\hline$\overline{0}$ & & $\begin{array}{l}\text { 爱 } \\
\text { 产 }\end{array}$ & 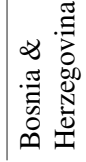 & & 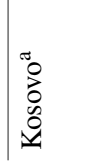 & 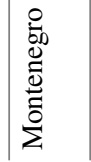 & 离 & 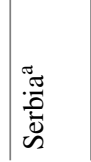 & \\
\hline
\end{tabular}




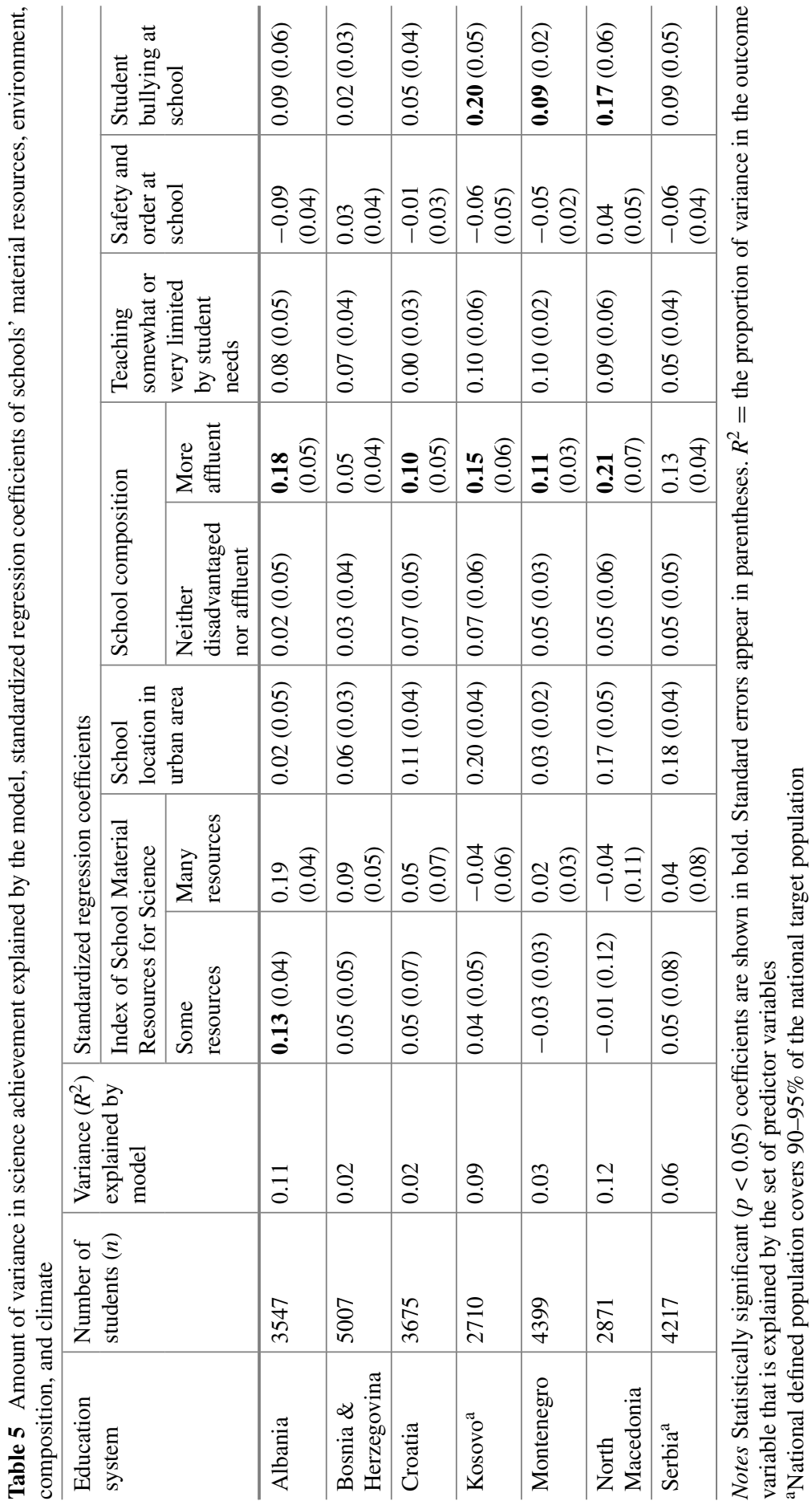


(Mullis et al., 2020). Regarding some elements of school climate, higher average achievement in mathematics and science, at both grade four and grade eight, was associated with students having a greater sense of school belonging and experiencing little or no bullying. At the system level, the results of PISA 2018 for 15-year-olds also indicated "that instruction hindered by a lack of educational materials was associated with lower reading scores in all participating countries and economies. School systems that showed more equity in the allocation of material resources tended to score higher in reading" (OECD, 2020, p. 196).

We found that the amount of material resources in schools was related to grade four students' mathematics and science achievement in four of the Dinaric participants (Albania, North Macedonia, and Serbia), and related only to their mathematics achievement in Croatia. We found that schools with more students coming from affluent backgrounds tended to have the highest achievement in every participating system except Kosovo. Other research found that that there was a stronger emphasis on academic success in schools that are better equipped (see chapter "Characteristics of Principals and Schools in the Dinaric Region"). According to their teachers' perceptions, almost all students in Albania to about half of the students in Croatia were taught in very safe and orderly schools. There was not a high prevalence of bullying in the Dinaric region, although around a third of students in Croatia and North Macedonia reported that they were bullied monthly or weekly; this is a worrying level of bullying, and educational professionals in the region should devote more attention to finding solutions to tackle this issue.

Although many education systems in the Dinaric region still have much to improve in terms of equipping schools with better material resources, our study highlights the importance of effective practice, and developing a supportive school climate and culture of achievement. "Ensuring that all schools have adequate and highquality material resources, and the appropriate support, is key if students from all backgrounds are to be given equal opportunities to learn and succeed at school" (OECD, 2020, p. 16). As the definition of school material resources has broadened to include ICT skills and the associated digital tools and resources, school systems face a whole new level of procurement.

Our study has confirmed that, beside the physical environment and material resources that support learning in schools, there are additional, less tangible dimensions of school life, which are equally important for the successful achievement of educational goals. The most important task of educational systems and school authorities is still to set and maintain both material factors (resources) and social factors of school functioning (such as safety, order, support, and emphasis on achievement goals), and often the core aim is to improve student achievement. But, ideally, schools should provide equal opportunities for students that come from challenging or deprived environments; it is important that schools are not just buildings but also active catalysts of change through learning processes. Theory and ILSA results suggest that a good physical environment and sufficient material resources, together with supportive teachers, the existence of peer practices (for teachers and students), innovative methods, an open climate for discussion, and willingness to cooperate with parents and/or the wider community, establishes a productive setting for better 
learning outcomes. Where schools do not have a shortage of material resources (such as space, equipment, or staffing), a critical factor for success is supporting healthy social relationships and fostering an open school climate, providing a school environment free from bullying and other stress factors. Our analyses showed that school-level variables only explained low levels of variance across the Dinaric region; consequently we conclude that home resources, the sociocultural capital of parents/guardians, and their willingness to participate in their child's schooling must play a major role in student achievement, together with students' attitudes toward the subject matter and their schools. While upgrading the material aspects of the educational environment is something that schools can influence and work hard on improving, good results can also be obtained by creating strong and healthy teaching and learning communities.

\section{References}

Bear, G., Yang, C., Pell, M., \& Gaskins, C. (2014). Validation of a brief measure of teachers' perceptions of school climate: Relations to student achievement and suspensions. Learning Environments Research, 17, 339-354. https://doi.org/10.1007/s10984-014-9162-1

Brand, S., Felner, R. D., Seitsinger, A., Burns, A., \& Bolton, N. (2008). A large scale study of the assessment of the social environment of middle and secondary schools: The validity and utility of teachers' ratings of school climate, cultural pluralism, and safety problems for understanding school effects and school improvement. Journal of School Psychology, 46, 507-535. https://doi. org/10.1016/j.jsp.2007.12.001

Burston, J., Dyer-Witheford, N., \& Hearn, A. (2010). Digital labour: Workers, authors, citizens. Ephemera, 10(3), 214-221. http://www.ephemerajournal.org/sites/default/files/pdfs/10-3ephem eranov10.pdf

Cohen, J., McCabe, L., Michelli, N. M., \& Pickeral, T. (2009). School climate: Research, policy, practice, and teacher education. The Teachers College Record, 111, 180-213. https://eric.ed.gov/? id=EJ826002

Drigas, A., \& Vasiliki, T. (2015). Lifelong learning and ICTs: A review. International Journal of Recent Contributions from Engineering Science \& IT, 3(2), 15-20. https://doi.org/10.3991/ijes. v3i2.4353

Eickelmann, B. (2011). Supportive and hindering factors to a sustainable implementation of ICT in schools. Journal for Educational Research Online/ Journal für Bildungsforschung Online, 3(1), 75-103. https://www.pedocs.de/volltexte/2011/4683/pdf/JERO_2011_1_Eickelmann_Sup

Fishbein, B., Foy, P., \& Yin, L. (2021). TIMSS 2019 user guide for the international database. TIMSS \& PIRLS International Study Center, Boston College. https://timssandpirls.bc.edu/tim ss2019/international-database/

Fraillon, J., Ainley, J., Schulz, W., Friedman, T., \& Duckworth, D. (2020). Preparing for life in a digital world: IEA international computer and information literacy study 2018 international report. Springer International Publishing. https://www.iea.nl/publications/study-reports/prepar ing-life-digital-world

Gregurović, M., \& Kuti, S. (2010). Učinak socioekonomskog statusa na obrazovno postignuće učenika: Primjer PISA istraživanja, Hrvatska 2006 [The effect of socioeconomic status on students' educational achievement: Example of PISA research, Croatia 2006]. Revija Za Socijalnu Politiku, 17(2), 179-196. https://doi.org/10.3935/rsp.v17i2.918

Hoy, W. K., Tarter, C. J., \& Kottkamp, R. B. (1991). Open schools/healthy schools: Measuring organizational climate. Sage. 
ICJ. (2010). Accordance with international law of the unilateral declaration of independence in respect of Kosovo, Advisory Opinion, I.C.J. reports 2010. International Court of Justice. https:// www.icj-cij.org/public/files/case-related/141/141-20100722-ADV-01-00-EN.pdf

Kutsyuruba, B., Klinger, D., \& Hussain, A. (2015). Relationships among school climate, school safety, and student achievement and well-being: A review of the literature. Review of Education, 3, 103-135. https://doi.org/10.1002/rev3.3043

Matković T., Dobrotić, I., \& Baran J. (2019). Što vrtić ima s tim? Pristup ranom i predškolskom odgoju i obrazovanju i reprodukcija društvenih nejednakosti u redovnom školovanju: analiza podataka PISA i TIMSS istraživanja [What's kindergarten got to do with it? Access to early childhood education and care and reproduction of social inequalities in regular education: Analysis of PISA and TIMSS Ddata]. Revija za sociologiju, 49(1), 7-35. https://doi.org/10.5613/rzs. 49.1.1

Martin, M. O., \& Mullis, I. V. S. (Eds.). (2013). TIMSS and PIRLS 2011: Relationships among reading, mathematics, and science achievement at the fourth grade-Implications for early learning. TIMSS \& PIRLS International Study Center, Boston College. https://timssandpirls. bc.edu/timsspirls2011/downloads/TP11_Intro.pdf

Martin, M. O., Mullis, I. V. S., Foy, P., \& Hooper, M. (2016). TIMSS 2015 International Results in Science. Retrieved from Boston College, TIMSS \& PIRLS International Study Center. http://tim ssandpirls.bc.edu/timss2015/international-results/

Meinck, S., Stancel-Piatak, A., \& Verdisco, A. (2018). Preparing the ground: The importance of early learning activities at home for fourth grade student achievement. IEA Compass: Briefs in Education 3. International Association for the Evaluation of Educational Achievement. https://www.iea.nl/publications/series-journals/iea-compass-briefs-education-ser ies/september-2018-preparing-ground

Mihaljević Kosor M., Malešević Perović L., \& Golem S. (2019). The role of international benchmarking in shaping educational policy in small European countries. In H. A. Ingpórsson, N. Alfirević, J. Pavičić, \& D. Vican (Eds.), Educational leadership in policy: Challenges and implementation within Europe (pp. 27-40). Palgrave Macmillan. https://doi.org/10.1007/978-3-31999677-6_3

Mullis, I. V. S., Martin, M. O., Foy, P., \& Hooper, M. (2017). PIRLS 2016 international results in reading. TIMSS \& PIRLS International Study Center, Boston College. http://timssandpirls.bc. edu/pirls2016/international-results/

Mullis, I. V. S., Martin, M. O., Foy, P., \& Hooper, M. (2016a). TIMSS 2015 international results in mathematics. TIMSS \& PIRLS International Study Center, Boston College. http://timssandpirls. bc.edu/timss2015/international-results/

Mullis, I. V. S., Martin, M. O., \& Loveless, T. (2016b). 20 years of TIMSS: International trends in mathematics and science achievement, curriculum, and instruction. TIMSS \& PIRLS International Study Center, Boston College. http://timssandpirls.bc.edu/timss2015/international-results/ timss2015/wp-content/uploads/2016/T15-20-years-of-TIMSS.pdf

Mullis, I. V. S., Martin, M. O., Foy, P., Kelly, D. L., \& Fishbein, B. (2020). TIMSS 2019 international results in mathematics and science. TIMSS \& PIRLS International Study Center, Boston College. https://timssandpirls.bc.edu/timss2019/international-results/

Martin, M. O., von Davier, M., \& Mullis, I. V. S. (Eds.). (2020). Methods and procedures: TIMSS 2019 technical report. TIMSS \& PIRLS International Study Center, Boston College. https://tim ssandpirls.bc.edu/timss2019/methods

OECD. (2019a). PISA 2018 results (Volume I): What students know and can do. OECD Publishing. https://www.oecd.org/pisa/publications/pisa-2018-results-volume-i-5f07c754-en.htm

OECD. (2019b). PISA 2018 results (Volume II): Where all students can succeed. OECD Publishing. https://www.oecd.org/pisa/publications/pisa-2018-results-volume-ii-b5fd1b8f-en.htm

OECD. (2019c). PISA 2018 results (Volume III): What school life means for students' lives. OECD Publishing. https://www.oecd.org/pisa/publications/pisa-2018-results-volume-iiiacd78851-en.htm 
OECD. (2019d). TALIS 2018 results (Volume I): Teachers and school leaders as lifelong learners. OECD Publishing. http://www.oecd.org/education/talis-2018-results-volume-i$1 \mathrm{~d} 0 \mathrm{bc} 92 \mathrm{a}-\mathrm{en} . \mathrm{htm}$

OECD. (2020). Education in the Western Balkans: Findings from PISA. OECD Publishing. https:// www.oecd-ilibrary.org/education/education-in-the-western-balkans_764847ff-en

Schulz, W., Ainley, J., Fraillon, J., Kerr, D., \& Losito, B. (2010). ICCS 2009 international report: Civic knowledge, attitudes and engagement among lower secondary school students in thirty-eight countries. International Association for the Evaluation of Educational Achievement. https://www. iea.nl/publications/study-reports/international-reports-iea-studies/iccs-2009-international-report

TIMSS \& PIRLS International Study Center. (2016). Press release: As global study TIMSS turns 20, new results show East Asian students continue to outperform peers in mathematics. TIMSS \& PIRLS International Study Center, Boston College. http://timss2015.org/wp-content/uploads/ 2016/T15-Press-Release-FINAL-11-29.pdf

TIMSS \& PIRLS International Study Center. (2018). TIMSS 2019 context questionnaires. TIMSS \& PIRLS International Study Center, Boston College. https://timssandpirls.bc.edu/timss2019/que stionnaires/index.html

UNESCO. (2014). Harnessing the potential of ICTs for literacy teaching and learning. UNESCO Institute for Lifelong Learning. Retrieved from https://unesdoc.unesco.org/ark:/48223/pf0000 229517

United Nations. (1999). Resolution 1244 (1999). Adopted by the Security Council at its 4011th meeting, on 10 June 1999. United Nations Security Council. https://digitallibrary.un.org/record/ $274488 ? \ln =\mathrm{en}$

United Nations Children's Fund. (2017). A familiar face: Violence in the lives of children and adolescents. UNICEF. https://data.unicef.org/resources/a-familiar-face/

Webb, M., \& Cox, M. (2004). A review of pedagogy related to information and communications technology. Technology, Pedagogy and Education, 13(3), 235-286.

Yin, L., \& Fishbein, B. (2020). Creating and interpreting the TIMSS 2019 context questionnaire scales. In M. O. Martin, M. von Davier, \& I. V. S. Mullis (Eds.), Methods and procedures: TIMSS 2019 technical report (pp. 16.1-16.331). TIMSS \& PIRLS International Study Center, Boston College. https://timssandpirls.bc.edu/timss2019/methods/chapter-16.html

Ines Elezović has been employed with the National Centre for External Evaluation of Education since 2008, working in the Research and Development Department and then in the Department for Quality Assurance in Education. At present, she is working on international projects as national research coordinator for the IEA PIRLS, TIMSS, and ICCS surveys. Drawing on acquired knowledge and work experience she has specialized in the sociology of education, methodology of large scale assessments, and research project cycles in education.

Beti Lameva is the head of the Sector for Exams, IT and Research at the National Examination Center in the Republic of North Macedonia. She has more than 20 years of experience in education research, establishing large-scale assessment and high-risk exams, data entry, cleaning, and processing. Beti has also been involved in international studies since TIMSS 1999 as a data manager. She is currently the national research coordinator for the international studies, TIMSS and PISA.

Falk Brese is a senior research analyst at IEA's Research and Analysis Unit. His research interests are in social inequalities and immigration, the transition of research results from reporting to policy implementation, as well as international large-scale assessment (ILSA) methodology. He has worked at IEA since 2000 and has ample experience with the implementation of ILSAs and analyzing respective data. He has a background in political science with a focus on policy formation and implementation. 
Open Access This chapter is licensed under the terms of the Creative Commons AttributionNonCommercial 4.0 International License (http://creativecommons.org/licenses/by-nc/4.0/), which permits any noncommercial use, sharing, adaptation, distribution and reproduction in any medium or format, as long as you give appropriate credit to the original author(s) and the source, provide a link to the Creative Commons license and indicate if changes were made.

The images or other third party material in this chapter are included in the chapter's Creative Commons license, unless indicated otherwise in a credit line to the material. If material is not included in the chapter's Creative Commons license and your intended use is not permitted by statutory regulation or exceeds the permitted use, you will need to obtain permission directly from the copyright holder.

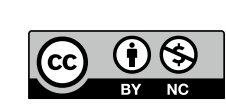

